\title{
Survey of Human Paragonimiasis with Intradermal Test in Wakayama Prefecture
}

\author{
Mitsuru Shirakawa*
}

\section{Introduction}

Paragonimiasis was developed in a female adult in Kibi-chô, Arita-gun, Wakayama Prefecture in $1967^{11}$, and 3 other cases in a family living in Wakayama City area were also confirmed to be infected with lung fluke in August 1968. These cases have been reported by the present author ${ }^{6 / 7)}$.

In Wakayama Prefecture, a total of 8 cases with human paragonimiasis, including the above 4 cases, have confirmed since 1892 .

However, no information was available as to academic problems or health and hygiene-related administrative problems such as the type of the infecting source and whether Wakayama Prefecture is an infected district or not.

In this connection, the staffs of the Department of Public Health of Wakayama Medical College (the present author being the professor and director at that time) performed surveys and investigations on the intradermal test for lung fluke on the resident of Wakayama Prefecture ${ }^{2)}$. The survey was carried out as a joint study with the Department of Zoology, Ohsaka City University Medical School (Professor : Hideo Tanaka) and Ohsaka Kiseichûbyo-Yobô Kyôkai (President : Dr. Kaoru Morishita $)^{2}$.

\section{Results}

1 ) Surveys in Ohtoh-mura, Nishimuro-gun, Wakayama Prefecture.

In 1967, a 19 y. o. boy, a resident in Ohtoh-mura, was diagnosed as being infected by pulmonary tuberculosis, and hospitalized for one year. The egg of lung fluke was then detected in the lung tissue resected by partial lobectomy, and this case was reported as paragonimiasis by $\mathrm{Oka}$ et $\mathrm{al}^{3)}$ at the Wakayama Medical Meeting in 1968. The reporters stated that the patient may had been infected at Ohtoh-mura area.

Because of the existence of this case, Mikawa district in Ohtoh-mura was selected for intradermal test ${ }^{2}$. This district is a remote and isolated small village in the hills and it is situated at the upper stream of the Hiki River located at the central region of Wakayama Prefecture. There are a few agricultural land in this district, thus the major industry is forestry. The population was 2,317 at that time. The examination was carried out during a period of 10-16, July 1968. The number of examinees is shown in Table 1. All of the examinees were tested by stool examination and by intradermal test for lung fluke.

As shown in Table 1,617 subjects $(62.8 \%)$ out of 982 examinees for stool examination had parasites' eggs. Among them, 163 (16.6\%) had the eggs of Ascaris lumbricoides, 28 (2.9\%) had that of the hookworm, $383(39.0 \%)$ had that of Trichuris trichiura, and 353 (35.9\%) had that of Metagonimus yokogawai. These results thus indicated this district to be a heavily infected district by intestinal parasites.

* Department of Hygiene, Miyazaki Medical College (Director : Prof. Mitsuru Shirakawa). 
Table 1. Intradermal test for paragonimus and stool examination in Mikawa District (Population 2,317) in Ohtoh-mura, Nishimuro-gun, Wakayama Prefecture. (July 10-16, 1968)

a) Intradermal test

\begin{tabular}{c|c|c|c}
\hline $\begin{array}{c}\text { No. of } \\
\text { examinees }\end{array}$ & Negative & Pseudo-positive & Positive \\
\hline $\begin{array}{c}708 \\
(100 \%)\end{array}$ & $\begin{array}{c}598 \\
(84.9 \%)\end{array}$ & $\begin{array}{c}68 \\
(9.7 \%)\end{array}$ & $\begin{array}{c}42 \\
(6.0 \%)\end{array}$
\end{tabular}

Remark : Paragonimus eggs in the positive's sputum and in the stool are negative.

b) Stool examination of parasites

\begin{tabular}{c|c|c|c|c|c|c}
\hline $\begin{array}{c}\text { No. of } \\
\text { examinees }\end{array}$ & Egg-carrier & $\begin{array}{c}\text { Ascaris } \\
\text { lumbricoides }\end{array}$ & Hook worm & $\begin{array}{c}\text { Trichuris } \\
\text { trichiura }\end{array}$ & $\begin{array}{c}\text { Metagonimus } \\
\text { yokogawai }\end{array}$ & Lung fluke \\
\hline $\begin{array}{c}982 \\
(100 \%)\end{array}$ & $\begin{array}{c}617 \\
(62.8 \%)\end{array}$ & $\begin{array}{c}163 \\
(16.6 \%)\end{array}$ & $\begin{array}{c}28 \\
(2.9 \%)\end{array}$ & $\begin{array}{c}383 \\
(39.0 \%)\end{array}$ & $\begin{array}{c}353 \\
(35.9 \%)\end{array}$ & $\begin{array}{c}0 \\
(0 \%)\end{array}$
\end{tabular}

A total of 708 subjects were tested by intradermal test for paragonimus. As shown in Table 1 , 598 were negative ( $84.9 \%), 68(9.7 \%)$ pseudo-positive and $42(6.0 \%)$ were positive to this test. All subjects with pseudo-positive and positive responses were then subjected to sputum examination. No eggs of paragonimus, however, could be detected. The stool examination mentioned above also did not show the presence of the egg.

Residents in this district, however, told us that some areas of the district were infected by paragonimus some years ago.

In the present study, the complement fixation test (CF-T) could not be performed on all the subjects with pseudo-and true-positivities to the intradermal test.

2 ) Intradermal tests performed at the Tokuda district of Kibi-chô, Arita-gun, Wakayama Prefecture.

As stated earlier, this district was chosen for epidemiological survey because of the occurrence of paragonimiasis in a house wife living in this district ${ }^{1,6}$. The surveys and examinations performed were as follows : a meeting for explaining the purpose and significance of the survey, to which 20 representative local peoples attended. Cooperation was asked there, and even healthy peoples were asked to be examined as many as possible.

During 4 days from 8 to 17, December, the intradermal test using VBS antigen and chest X-ray examination as a regular health test by Yuasa Health Center in the district were simultaneously carried out. Stool examination was also performed on 99 subjects.

Although the total number of examinees had to be limited to a considerable extent, because the examination was made at the end of the year, a total of 241 subjects were tested as shown in Table 2. Among them 7 subjects ( $2.9 \%$ ) were found to be positive to the intradermal test. Blood samples were immediately collected from them, and the serum specimens were sent to the Department of Parasitology, Chiba University, for serological examinations. The result, however, showed that all of the cases thus tested were negative to CF-T, indicating that there was no paragonimiasis at all in these subjects.

Stool examination was carried out on 99 subjects, and 23 (23.2\%) were egg-carrier, $12(12.1 \%)$ 
Table 2. Results of examinations

a) Intradermal test positive : $7 / 241$ examinees $=2.9 \%$

\begin{tabular}{|c|c|c|c|c|c|c|c|c|c|}
\hline \multirow[b]{2}{*}{ No. } & \multirow{2}{*}{ Name } & \multirow[b]{2}{*}{ Sex } & \multicolumn{2}{|c|}{ VBS antigen } & \multicolumn{2}{|c|}{ Control } & \multirow{2}{*}{$\begin{array}{c}\text { Difference } \\
\text { of } \\
\text { swelling }\end{array}$} & \multirow{2}{*}{$\begin{array}{l}\text { Judge- } \\
\text { ment }\end{array}$} & \multirow{2}{*}{$\begin{array}{l}\text { C.F.T. } \\
\text { Antibody } \\
\text { titer }\end{array}$} \\
\hline & & & $\begin{array}{c}\text { Just after } \\
\text { the test }\end{array}$ & $\begin{array}{c}\text { After } 15 \\
\text { minutes }\end{array}$ & $\begin{array}{l}\text { Just after } \\
\text { the test }\end{array}$ & $\begin{array}{l}\text { After } 15 \\
\text { minutes }\end{array}$ & & & \\
\hline 1 & T.H. & Female & $2 \times 2 \mathrm{~mm}$ & $7 \times 12 \mathrm{~mm}$ & $3 \times 3 \mathrm{~mm}$ & $2 \times 3 \mathrm{~mm}$ & $8 \mathrm{~mm}$ & + & - \\
\hline 2 & M.K. & Male & $4 \times 4$ & $12 \times 12$ & $4 \times 5$ & $5 \times 5$ & 8 & + & - \\
\hline 3 & T.Y. & Male & $4 \times 5$ & $11 \times 12$ & $4 \times 5$ & $3 \times 4$ & 7 & + & - \\
\hline 4 & H.S. & Male & $6 \times 6$ & $11 \times 16$ & $5 \times 5$ & $5 \times 5$ & 8 & + & - \\
\hline 5 & Т.O. & Male & $4 \times 4$ & $11 \times 11$ & $4 \times 5$ & $6 \times 8$ & 5 & + & - \\
\hline 6 & Y.H. & Female & $4 \times 5$ & $9 \times 10$ & $4 \times 5$ & $3 \times 4$ & 5 & + & - \\
\hline 7 & K.T. & Male & $4 \times 4$ & $8 \times 10$ & $4 \times 3$ & $4 \times 6$ & 5 & + & - \\
\hline
\end{tabular}

b) Results of stool examination

\begin{tabular}{c|c|c|c|c|c}
\hline $\begin{array}{c}\text { No. of } \\
\text { examinees }\end{array}$ & $\begin{array}{c}\text { No. of } \\
\text { egg carrier }\end{array}$ & $\begin{array}{c}\text { Trichuris } \\
\text { trichiura }\end{array}$ & $\begin{array}{c}\text { Metagonimus yokogawai, } \\
\text { Heterophyes heterophyes }\end{array}$ & $\begin{array}{c}\text { Metagonimus yokogawai, } \\
\text { Trichuris trichiura }\end{array}$ & lung fluke \\
\hline 99 & 23 & 8 & 12 & 3 & 0 \\
$(100 \%)$ & $(23.2 \%)$ & $(8.1 \%)$ & $(12.1 \%)$ & $(3 \%)$ & $(0 \%)$
\end{tabular}

were with Metagonimus yokogawai, 8 (8.1\%) were with Trichuris trichiura, and $3(3.0 \%)$ were combinedly infected by Metagonimus yokogawai and Trichuris trichiura. The egg of paragonimus, however, could not be detected at all by stool examination.

3 ) Intradermal test on the inpatient of Wakaura Cetral Hospital.

This hospital is a specialized sanatorium (Director : Kanae Endo, M. D.) situated at Wakaura region of Wakayama City. About a quarter of the inpatients, namely 68 patients, were examined with intradermal test using VBS antigen ${ }^{4), 5}$. Only one patient (1.5\%) was found to respond positively. Complement fixation test for paragonimiasis performed at the Department of Parasitology, Chiba University, showed negative response. Thus, paragonimiasis was denied in this patient.

\section{Summary and Discussion}

Intradermal test for paragonimus, and stool and sputum examinations were performed on residents in 2 particular districts in Wakayama Prefecture and on inpatients at a sanatorium in the same prefecture, the 2 districts selected being those with the history of paragonimiasis. In Ohtoh -mura and Kibi-chô districts, only a small population of residents were found to be positive to the skin test. Moreover, all serum specimens from such positive subjects did not contain CF antibody. Stool and sputum examinations also indicated the complete absence of the egg of paragonimus. Despite the recent occurrence of paragonimiasis in these districts, no paragonimiasis-case was discovered by the present survey.

As shown in Table 3, paragonimiasis patients are used to be contaminated in inpatients in sanatoriums. In the case of the inpatients of Wakaura Central Hospital, however, no such case could be found out by examination on a quarter of total inpatients.

Wakayama Prefecture is economically poorer than other developed prefectures, and the incidence of parasitisms is quite high not only in city areas but also in rural and hill areas. However, this 
Table 3. Result of intradermal test for paragonimus of inpatients in sanatoriums and hospitals.

\begin{tabular}{|c|c|c|c|c|c|c|}
\hline \multirow{2}{*}{$\begin{array}{l}\text { Hospitals or } \\
\text { Sanatoriums }\end{array}$} & \multirow{2}{*}{ Examiners } & \multirow{2}{*}{$\begin{array}{c}\text { No. of } \\
\text { Examinees }\end{array}$} & \multicolumn{2}{|c|}{ Judgement } & \multirow{2}{*}{$\begin{array}{l}\text { Positive determined } \\
\text { as paragonimiasis }\end{array}$} & \multirow{2}{*}{ Remarks } \\
\hline & & & + & \pm & & \\
\hline $\begin{array}{l}\text { National } \\
\text { Numazu Hospital }\end{array}$ & $\begin{array}{l}\text { Ohba and } \\
\text { Okada } \\
\qquad(1956)\end{array}$ & $\begin{array}{c}203 \\
(100 \%)\end{array}$ & $\begin{array}{c}8 \\
(3.9 \%)\end{array}$ & $\begin{array}{c}3 \\
(1.5 \%)\end{array}$ & $\begin{array}{c}5 \\
(2.5 \%)\end{array}$ & \\
\hline $\begin{array}{l}\text { Akae Sanatorium } \\
\text { (Miyazaki Pref.) }\end{array}$ & $\begin{array}{l}\text { Hayashi and } \\
\text { Komaki } \\
\qquad(1957)\end{array}$ & $\begin{array}{c}39 \\
(100 \%)\end{array}$ & $\begin{array}{c}13 \\
(33.3 \%)\end{array}$ & $\begin{array}{c}6 \\
(15.4 \%)\end{array}$ & $\begin{array}{c}13 \\
(33.3 \%)\end{array}$ & \\
\hline $\begin{array}{l}\text { Ehime Sanatorium } \\
\text { (Ehime Pref.) }\end{array}$ & $\begin{array}{l}\text { Akamatsu \& } \\
\text { Yamamoto } \\
(1959)\end{array}$ & $\begin{array}{c}970 \\
(100 \%)\end{array}$ & $\begin{array}{c}57 \\
(5.9 \%)\end{array}$ & $\begin{array}{c}52 \\
(5.4 \%)\end{array}$ & $\begin{array}{c}12 \\
(1.2 \%)\end{array}$ & \\
\hline $\begin{array}{l}\text { Deme Sanatorium } \\
\text { (Ehime Pref.) }\end{array}$ & $\begin{array}{l}\text { The Welfare } \\
\text { Ministry } \\
\text { (1958) }\end{array}$ & $\begin{array}{c}243 \\
(100 \%)\end{array}$ & $\begin{array}{c}27 \\
(11.1 \%)\end{array}$ & $\begin{array}{c}5 \\
(2.1 \%)\end{array}$ & $\begin{array}{c}13 \\
(5.3 \%)\end{array}$ & $\begin{array}{l}\text { Four patients } \\
\text { combined } \\
\text { tuberculosis }\end{array}$ \\
\hline $\begin{array}{l}\text { Kôchi Sanatorium } \\
\text { (Kôchi Pref.) }\end{array}$ & $\begin{array}{l}\text { Do } \\
\qquad(1958)\end{array}$ & $\begin{array}{c}239 \\
(100 \%)\end{array}$ & $\begin{array}{c}10 \\
(4.2 \%)\end{array}$ & $\begin{array}{c}8 \\
(3.3 \%)\end{array}$ & $\begin{array}{c}10 \\
(4.2 \%)\end{array}$ & $\begin{array}{l}\text { One patient } \\
\text { combined with } \\
\text { tuberculosis }\end{array}$ \\
\hline $\begin{array}{l}\text { Hyûga Sanatorium } \\
\text { (Miyazaki Pref.) }\end{array}$ & $\begin{array}{l}\text { Do } \\
\qquad(1958)\end{array}$ & $\begin{array}{c}115 \\
(100 \%)\end{array}$ & $\begin{array}{c}6 \\
(5.2 \%)\end{array}$ & $\begin{array}{c}4 \\
(3.5 \%)\end{array}$ & $\begin{array}{c}3 \\
(2.6 \%)\end{array}$ & \\
\hline $\begin{array}{l}\text { Seifû Sanatorium } \\
\text { (Ogushi, Yamaguchi } \\
\text { Pref.) }\end{array}$ & $\begin{array}{l}\text { Do } \\
\qquad(1958)\end{array}$ & $\begin{array}{c}195 \\
(100 \%)\end{array}$ & $\begin{array}{c}1 \\
(0.5 \%)\end{array}$ & $\begin{array}{c}2 \\
(1.0 \%)\end{array}$ & $\begin{array}{c}1 \\
(0.5 \%)\end{array}$ & \\
\hline $\begin{array}{l}\text { Wakaura } \\
\text { Central Hospital }\end{array}$ & $\begin{array}{l}\text { Shirakawa, } \\
\text { Yamasaki } \\
\text { and Endô } \\
(1969)\end{array}$ & $\begin{array}{c}68 \\
(100 \%)\end{array}$ & $\begin{array}{c}1 \\
(1.5 \%)\end{array}$ & 0 & 0 & $\begin{array}{l}\text { C.F.T. } \\
\text { Antibody titer } \\
\text { negative }\end{array}$ \\
\hline
\end{tabular}

prefecture appears not to be the district affected by paragonimus.

\section{Conclusion}

As a result of intradermal test, and stool and sputum examinations on the residents of 2 districts with the history of paragonimiasis and on the inpatients of a sanatorium, no case with paragonimiasis could be found out. On the basis of this result, Wakayama Prefecture seems not to be a district affected by lung fluke.

\section{Acknowledgement}

I would like to express my sincere thanks to Miss Chisato Yamasaki for her technical assistance in various examinations and to Dr. Kanae Endo, Director of Wakaura Central Hospital in Wakayama City, for his coordination. Moreover, the author would like to thank Professor Muneo Yokogawa of the Department of Parasitology, Chiba University School of Medicine, Professor Hideo Tanaka of the Department of Medical Zoology, Osaka City University Medical School, President Dr. Kaoru Morishita of Osaka Preventive Medicine Association for Parasite, and their coworkers for their advices and suggestions, and for performing various tests for this investigation.

\section{References}

1) Sumita, D., Yamasaki, C., and Shirakawa, M.: A study on the treatment of a human 
paragonimiasis and the lapse of chest roentgenograms. Jap. J. Parasitol. 18, 681-682, 1969.

2) Tanaka, H. et al: A survey on the infection rate of intestinal parasite and skin reaction of lung fluke in Ohtoh-mura, Wakayama Prefecture. (Rep. 1) Jap. J. Parasitol. 17, 597-598, 1968.

3 ) Oka. H. and Nishimura, T.: A case of human paragonimiasis determined histopathologically from the resected lung tissues. J. Wakayama Med. Soc. 19, 335, 1968.

4) Shirakawa, M. and Yamasaki, C.: Survey of paragonimiasis with intradermal test in Wakayama Prefecture. Jap. J. Parasitol. 19, 349-350, 1970.

5 ) Shirakawa, M., Yamasaki, C., and Fujii, M.: Survey on skin tests for lung fluke in some districts in Wakayama Prefecture. (Rep. 2) Jap. J. Parasitol. 20 (Suppl.), 51, 1971.

6 ) Shirakawa, M.: Survey and investigations on occurrence of human paragonimiasis in Wakayama Prefecture. J. of Jap. Assoc. of Rural Med., 32, 197-201, 1983.

7 ) Shirakawa, M. : A case of human paragonimiasis and its treatment. J. of Jap. Assoc. of Rural Med., 32, 879-886, 1983.

\section{和歌山県に扮ける肺吸虫皮内反応の調査成績について}

白川 充*

かつて，和歌山県内で，肺吸虫症患者が発生した 2 地区の住民と, 結核専門病院に入院中の患者等につい

* 宮崎医科大学衛生学教室（主任：白川 充教授）
て, 肺吸虫皮内反応と, 同時に検便や検痰等を実施し た結果, 被検者には肺吸虫症患者を 1 人も発見するこ とはできなかった。したがって和歌山県は肺吸虫につ いては，流行地とはいえないようである。 